\title{
Investigating Fairness in Economic Transactions: Evidence in Belief Systems
}

\author{
Hazik Mohamed \\ Stellar Consulting Group, Singapore, hazik@stellarcg.com
}

Received: November 22, 2018 Revised: December 12, 2018

\begin{abstract}
Fairness is one of the central institutional pillars of Islamic law, and its inherent legal framework dictates, among other things, clarity and ethical behaviors in all our endeavors. Righteous behaviors form the foundation of fairness and justice. This paper attempts to address deep religious understanding in human behavior for fairness and justice so as to use religious values in productive economic behaviors, like the sharing risk and benefits in mutual agreements. The methodology of this study assesses the behavior of the subject pool (players representative of Muslims and non-Muslims) through the Ultimatum Game that was designed to test fairness and experiment in decision-making to measure fairness in economic transactions and to observe the level of religious-specific acceptance norms. This paper provides an actual behavioral investigation into how people (Muslims and nonMuslims) behave in real life, whether it is in accordance to what their religion prescribes to them or otherwise. In terms of fairness in contracting, non-Muslims performed a little bit better than Muslims but there were significant differences between the primed and unprimed subjects in the Muslim and non-Muslim groups where it was positive for the Muslim group and negative for the non-Muslim group.
\end{abstract}

Keywords: Behavioral rules, Religious Framing, Cultural Heuristic, Equality, Ultimatum Game.

JEL Classification: D30; D90; P47

@ IJIEF 2019 published by Universitas Muhammadiyah Yogyakarta, Indonesia All rights reserved

DOI:

https://doi.org/10.18196/ijief.127
Web:

http://journal.umy.ac.id/index.php/ijief/article/view/127

Citation:

Mohamed, H. (2019) Investigating Fairness in Economic Transactions: Evidence in Belief Systems. International Journal of Islamic Economics and Finance (IJIEF), 1(2), 123-144. DOI: https://doi.org/10.18196/ijief.127

\footnotetext{
* This research was made possible through financial support provided by the MOHE FRGS2015-1 and UM-INCEIF research grant.
} 
Mohamed| Investigating Fairness in Economic Transactions: Evidence in Belief Systems

\section{Introduction}

If there was one collective criticism of conventional economics, it would be that the study of economics has centered largely on efficiency, and more procedural aspects of transactions and its consequences. Increasingly, such critics opined that economics has inadequately focused on substantive areas crucial in maximizing utility in living a good and moral life, which emphasize virtues like trust, equality, fairness, happiness and the well-being of future generations. Some extreme critics even go so far to believe that the focus on efficiency and productivity is a well-crafted design for domination to keep resources in the hands of the few who are powerful and wealthy.

The Italian economist Vilfredo Pareto defined the modern conventional economic characterization of efficiency (called Pareto efficiency)as basically almost the same understanding to that of the gross domestic product. In that view, the more productive a nation is (i.e. the more things they produce like goods and services), the fewer resources they will be wasting by being idle and unproductive. In the utopian world of efficiency, or Pareto optimality, there exist a state where the economy is so efficient that one party cannot receive any more without depriving someone else. Alternatively, perfect efficiency can be viewed as a state where free-riding is not possible. Being able to measure efficiency will enable economists to capture which economic factors (including policies, initiatives and allocations) are not optimal. And as a result, new policies formulated with efficient institutions really can make things better for everybody. The true strength of the efficiency concept is that it emphasizes on small but steady advancement. Instead of making huge changes that can disrupt social norms, the efficiency concept focuses on finding policy tweaks that institutions can make everyone a bit better off than before.

Conversely, the counter argument for the efficiency concept is the provision of available resources at any one time. Nations that produce more today will leave fewer resources for the future generation tomorrow -Pareto optimality today may be disenfranchising the future generation. As such, economists have to understand the static version of the efficiency concept (efficiency at any one time) versus dynamic efficiency, which is efficiency over time. Stakeholders and governments must be able to balance both so that the provision of resources can be made to ensure sustainability of the nation moving forward into the future. Furthermore, the consequences of static efficiency such as inequality, has become a looming issue in the advanced economies that such trade-offs between efficiency and equality can no longer be ignored in order to protect the survival of those nations.

IJIEF: InternationalJournal of Islamic Economics and Finance, 1(2), 123-144 |124 
In this paper, we wanted to study fairness in transactions using the welldocumented experimental game called the Ultimatum Game. In our experiment, we will group our sample groups into Muslims and non-Muslims in order to make distinction in the rootedness of fairness in religious traditions and belief systems. This research will be using a priming instrument to heighten religious saliency in the subjects against control groups which are unprimed. The experiment was carried out in Singapore and then repeated in Malaysia, with actual cash incentives within the game scenario played out by selected unbiased test subjects.

\section{Literature Review}

\section{Between Equality and Fairness, What do People Want?}

The philosopher Harry Frankfurt argues that economic equality has no real value and it is a grouse that people do not realize that they do not have. In his 2015book, On Inequality, he contends that it is a moral but a psychological claim, and he gives evidence that if people take the time to reflect, they will realize that inequality is not really what disturbs them.

He makes the case that most people are distressed by what they see as unjust causes of economic difference, something that is perfectly understandable. People become more concerned by the potential consequences of economic difference. They imagine it as consequences that will disintegrate democratic societies, or increases crime and result in lawlessness, hence reduces over all happiness and the ability to enjoy a good life. Above all, most people are concerned about poverty - not only that the disenfranchised have less, but "that those with less have too little". Instead, Frankfurt argues that most people are not really bothered by inequality per se. He makes an important distinction by pointing out that very few people are uncomfortable about the inequalities between the incredibly rich and the well-off, even though their wealth differences might be greater, both absolutely and proportionately, than inequalities between the moderately well-off and those considered poor. By contrast, he described a state where everybody suffered equal poverty but, he says, most people would not prefer that to our current state where we enjoy the world as it is with some inequality. Therefore, when we investigate deeper, "equality" cannot be what we really value nor "inequality" is what distresses us.

Behavioral-based researchers have discovered that if you let kids distribute things to strangers, they have a strong inclination towards equal divisions, even in extremeconditions. Research psychologists Alex Shaw and Kristina Olson (2012) found that when they told children between the ages of six and 
eight about two boys, Dan and Mark, who had cleaned up their room and were to be rewarded with erasers. However, there were 5 erasers, so a fair division was impossible due to five erasers for the two boys. Children irresistibly reported that the experimenter ought to throw away the extra fifth eraser instead of having to form an inequitable division. They did so even if they could have given the eraser to Dan or Mark without the other one knowing, so they could avoid eliciting anger, discontentment or jealousy. Such responses appear to indicate an inborninstinct for equal distribution and justice - they can be interpreted as a wish for fairness. Additionally, the equal distribution was purely because the children understood that Dan and Mark did equal work hence they ought to get an identical reward. But once Shaw and Olson changed the scenario by telling the youngsters "Dan did additional work than Mark," they were quite comfortable giving three to Dan and two to Mark. In simple terms, they were fine with unequal distribution, so long as it was fair and just. Our observations from associated studies of children, adults and remote tribes is an instinctive want for fair distribution or just treatment, and a very fervent goal not to get less than others (lose or low in standing). And there is no evidence to say that humans prefer equality for others without any corresponding effort on their part.

\section{Contractual Fairness}

Experimental evidence from previous research appears to point out that in contractual agreements, counterparties have a clear inclination for less complete contracts although the classical self-interest economic axiom forecasts that they would choose the more complete contract (Fehr \& Schmidt, 2000). In their experiments, the explicit contract principals explicitly conditioned a fine on the agent's deviation from a desired effort level. In the implicit contract they promise to pay a bonus after they have observed the agent's effort. The promise was, however, not binding. Fehr \& Schmidt's theoretical analysis illustrates that fairness concerns can explain this inclination for less completeness. They found that fair counterparties seem to keep their promises which provides strong monetary incentives through an incomplete contract, whereas selfish principals are likely to freeride and exploit the agents. Fairness, as they have termed it is the reciprocal response, even in the absence of any material benefits, and not a form of altruism or unconditional kindness.

The concept of mutual agreement of traditional contract law focused primarily on "contractual certainty" regarding contract terms. This concept of certainty is reflected in the idea that an offer and acceptance should be a "mirror image" of one another (DiMatteo, 1995). Thus, if the terms are not 
equal, then there could not be evidence of contractual intent. The notion of "fairness of exchange" have provided rationalizations for the relaxing of the stringent application of traditional contract doctrine and for the expansion of its remedial options (Atiyah, 1985). As such, DiMatteo called for a "new spirit of contract" formulation and where the underlying premise it is supported by the belief that the courts should expand their analyses beyond the words of the instrument. This expanded analysis takes into consideration the "equities" of the overall transaction, including how subsequent events may call for an "equitable reformation" of the contract. For example, all contracts should be equitably reformed to include the obligations of "good faith" and "conscionability."

But as much as certainty is assumed, there is significant uncertainty that is possibly not communicated through verbal or written agreements. The certainty and comfort provided by classical contracts quickly dissipates when there is disputes or defaults for various reasons. Where there are missing elements within the traditional contract's equation, the courts and judiciary have to depend on the notion of "justifiable reliance" to deal with such disputes or breaches to launch the realm of contract remedies to distributing legal entitlements. And these differ slightly between legal systems:

i. Civil law describes and limits individual rights with respect to contracts (including business relationships), torts and statutes. Civil law nations expect their legislatures to codify laws that anticipate contingencies.

ii. Common law is a collection of judge-made principles that reflect usages and customs embodied in court decisions handed down from earlier times. Common law nations expect their courts to make caseby-case decisions that together comprise the law of contracts and torts, and this is known as the Doctrine of Stare Decisis. Its judges were expected to adapt the law to the changing conditions in society, i.e. fill the gap left by statutes, protect individual rights as well as to give meaning to parliamentary intention (respecting the parliamentary opinion).

iii. Sub-Saharan Law consists of a long tradition of unwritten customs that focus primarily on resolving disputes among tribal families and individuals. Tribal judges often assume the role of arbitrator or mediator. It should be noted that one needs to be mindful of the differences between law as written and law as practiced.

iv. East Asian Law typically covers China, Japan, Korea and Taiwan and it is the Confucian ideal of the family. The use of a formal legal system by individuals and businesses is viewed as disruptive to the societal goal of harmony. 


\section{Contractual Agreements and Fairness in Islam}

In comparison, Islamic law regulates contractual relationships in a way that is viewed as different from that of common and civil law. The Qur'an and Sunnah are the sources of the Shari'ah that establishes the types of contracts admissible to the faithful, their rights, and obligations. Islamic law determines the general theory of contracts comparable to its Western counterparts. The Shari'ah plays the role of a moral (or ethical) code, in which general principles are included through the jurisprudence of Islamic scholars (figh). Parties to a contract are also free, with some limitations, to place stipulations in a contract. These clauses cannot negate the legal purpose of a contract, or violate specific laws included in the Qur'an or the Sunnah (Arabi, 1998), which are the primary sources for Islamic jurisprudence. The model of contracts under Islamic law is closely linked to its conduct of the bona fides and pactasuntservanda principles. Good faith is very strongly instituted in the Islamic legal tradition. The commitment of Muslims with respect to their contractual obligations is binding not only in relation to other Muslims, but also towards non-believers. A contract in Islamic law is often deemed as not just secular law between the parties, but also a law "that is literally a sacred law between the parties" (Habachy, 1962: 467).

In general, Islamic law safeguards all worldly transactions, including economic activities, on written contracts with witnesses. Even the Primordial Covenant between the Creator and humans (the Mithaq) is essentially a spiritual faith-driven agreement between creation and the One whom they believe as the one and only Creator, which imposes the obligation on humans to recognize the Creator as the sole Provider and Sustainer (Rabb) of Life. From a behavioral perspective, that understanding should translate to a consciousness that their conduct on the earth will conform with the duties imposed by their Law-giver. Faithfulness to the terms of the Primordial Covenant (and all subsequent transactional contracts) should encompass establishing all forms of justice (distributive, retributive and restorative), incentives for compliance and retribution for violation. In fact, Judgment Day holds the ultimate accountability when every human beingis called on their fulfillment of obligations according to the terms and conditions of the Primordial Covenant. In an explicit and unmistakable verse, the Creator commands through His Word in the Qur'ān: "... fulfill the Covenant of Allåh," (Qur'ān, 6:152), and then generalizes this obligationto all contracts: "... fulfill all contracts," (Qur'ān, 5:1). Thus, the devotion to the terms of every contract, promise, pledge, or oath to carry out obligations that has been designated becomes a duty under the Primordial Covenant. 
Islam prescribes writing down contractual agreements as key enablers for fairness in trade and commerce which record mutually-agreed terms for accountability or dispute resolution. The significantly long Qur'anic verses of Surah Al-Baqarah in verses 282 and 283, enjoins Muslims to put into writing any debt or agreements for accountability in discharging one's obligations according to that agreement. As such, Muslim trade merchants trusted an Islamic legal structure for the purposes of accounting and liability, while Muslim scholars classified legal standards and acted as arbitrators in trade disputes. Dispute can be avoided if parties involved can inculcate the spirit of sincerity in their contracts (Danuri,et al., 2015) through good intent, proper disclosure, and effective risk management through risk sharing.

\section{Previous Studies}

In 1986, Kahnemann, et al. (1986) questioned the assumption that fairness is irrelevant to economic analysis. They believed that even profit-driven firms will succumb to individuals who are able to punish unfairness and resist unfair transactions. They conducted three experiments that showed that people are willing to enforce fairness. In other experiments, Fehr and Schmidt (1999) find that there is strong evidence that people exploit their bargaining power in competitive markets but not in bilateral bargaining situations. Their research show that if some people care about equity the enigmasof free-riding on voluntary cooperation and punishment costs can be resolved. It turns out that the economic environment determines whether the fair types or the selfish types dictate behavioral norms.

Li \& Jain (2015) found that, contracting parties are expected to be fair, reasonable, and conscionable, and requires parties to conduct themselves in good faith and to co-operate towards achieving the objective of the contract. However, Atiyah (1995) finds that there are issues with reconciling ideas of fairness with market flexibility in times of shortage and the difficulties of creating suitable legal remedies to deal with contracts made in imperfect market conditions. She focused on bargaining and its procedures in order to discuss the substantive justice of contractual agreements. In their experiments on social preferences, Charness and Rabin (2002) found that subjects are more concerned with increasing social welfare - sacrificingto increase the payoffs for all recipients, but they are also motivated by reciprocity: they withdraw willingness to sacrifice to achieve afair outcome when others are themselves unwilling to sacrifice, and sometimes punish unfair behaviors.

Children respond positively to individuals who favor them and also to individuals who are fair. Shaw, et al. (2012) tested to see which preference 
dominates in children and under what circumstances. They found that creating a competitive context increases children's preference for favoritism instead of fairness. They also found that in a third-party context, children value fairness over generosity. For organizations, Sedikides, et al. (2008) discussed procedural fairness (whether the organizational decision-making process is perceived as fair) whose complexities have profound psychological effects on organizational members through corporate messaging relevant to the self. Specifically, they categorized different types of self (individual, collective, relational) and, more importantly, to different motives within each type of self. As such, procedures satisfy the motives of uncertainty reduction and self-enhancement (individual self), the motives of reputation and status (collective self), and the motives of belongingness and respect (relational self). Herbert Simon (1976) had initially intelligently distinguished rational behavior as "substantive" and "procedural" as the latter is primarily concerned with process rather than outcome. While economists viewed rationality from a substantive definition, psychologists viewed rationality in procedural terms. On governance, Tyler (1994) found that procedural justice judgements influences assessments of the legitimacy of a governing authority. He did not find demographic (age, gender, income, education, ideology, race) differences on such assessments on legitimacy. His findings suggest that procedures give a credible foundation for maintaining public support in the face of differing positions on policies.

\section{Methodology}

The methodology is designed to evaluate the behavior of the subject pool (players representative of the Muslims and non-Muslims) in a given game (Ultimatum Game) that will test the rules of fairness in transactions. The same Ultimatum Game will be played by the Muslim and non-Muslim groups. It is a simple one-off game, in which the players simultaneously and independently choose their actions, and they do so only once. The instructions in a session will be read at the beginning of each game. The game administrators will use neutral terminology to avoid influencing the participants' decisions and choices. At the end of each session, the data is tabulated for final analysis later once all sessions have been consolidated, to examine the decisions made by the different groups. The test subjects do not know what is being tested for, to obtain neutrality and allows us to extract actual behavioral responses from the scenario outcomes. In addition, we employ a priming instrument created by Shariff and Norenzyan (2007) to statistically control for religious effects, that is, to segregate the Islamicsalient subjects from non-Islamic subjects. 


\section{Priming Instrument}

The consolidated experimental outcomes will be investigated for statistical significance, in particular, for the possible variations between Muslim and non-Muslim behaviors. As mentioned, we will employ the priming instrument created by Shariff and Norenzyan (2007) to separate the Islamicsalient subjects' behaviors within the Muslim group as well as the religioussalient subjects within the non-Muslim group via sentence-unscrambling task. The basic idea is that priming a social category temporarily increases the strength of affiliation with that category. The benefit of this priming instrument is that in the action of unscrambling the sentences, the subjects will be subtly primed to enhance their religious sentiments. This priming instrument is meant to be refined as compared to blatant primes. Previous studies have proven that indirect primes are more reliable in influencing behaviors to conform to norms (Wheeler and Petty, 2001).This helps immensely in inferring the experimental outcomes within our theoretical framework of self-categorization. Behaviors that have deeper association with a category causes the subjects to behave towards that category's norms, so evaluating primed and unprimed behavior allows us to estimate what the norms are and how they are reflected in normal behavior.

\section{The Ultimatum Game (Testing for Fairness in Contracts)}

The Ultimatum Game is a popular game in experimental game theory which is played between two subjects where the first player is referred to as the "offerer" and the second player is referred to as the "responder" in our research. The two players will be playing for $\$ \$ 20$ in Singapore and RM20 in Malaysia. Player 1 makes an offer to player 2 (responder) of $\$ \$ x x / R M x x$ from a total of S\$20/RM20. If the responder accepts the offer, then the offerer retains $\mathrm{S} \$ / \mathrm{RM}(20-\mathrm{xx})$ and responder receives the balance, i.e. what is offered. If the offer is rejected, then both players end up with nothing.

Under an axiomatic assumption in classical conventional economics, player 1 would give player 2 the lowest possible amount, which in this case could be an offer of a dollar/ringgit. Since the offer of a dollar/ringgit has made the player 2 better off, he/she should accept the dollar/ringgit. Although it made player 1 seem miserly or cheap, nonetheless player 2 made a dollar out of it. However, this assumed logic is flawed when we observe how people actually behave when faced with this decision in reality. Previous experiments using the Ultimatum Game showed that players consistently reject offers which are too low (offers which are lower than a quarter of the full amount), and players who want their offers accepted must offer more than the lowest amount, which is usually half of the full amount. This unexpected behavior 
Mohamed| Investigating Fairness in Economic Transactions: Evidence in Belief Systems

provides some real insight into actual human behavior and how the mind perceives distributive and retributive fairness.

From a sociological perspective, the Ultimatum Game illustrates the inborn human unwillingness to accept injustice or unfair outcomes. Devotion to the social contracts entered into- spoken or unspoken, are expected and linked to the fulfillment of obligations incurred under the stipulation of terms and conditions of acceptable behaviors which include establishing justice, rewarding fairness and punishing selfishness. The penchant to reject small offers may also be seen as germane to the concept of dignity and honor.

\section{Details of Test Subjects}

For our experimental investigations, we carried out the games in two different cities - Singapore and Kuala Lumpur - and though they had similar demographics, their respective institutions may somewhat vary in terms of performance as well as quality. Our sample size was limited by the funding made available to us resulting in sample sizes of 30 in Singapore and 40 in Malaysia. Though modest, our sample still had a good spread of age, education, gender and income instead of limiting to undergraduate or graduate groups, like those studies conducted in the U.S, which then limits the sample in terms of age, education and income levels. Also, there is less variation in the Muslim community in Singapore and Kuala Lumpur which is predominantly Sunni and follow the Shafi'e school of thought (mazhab).

Table 1.Decision Rules, Payoffs and Sample size.

\begin{tabular}{llll}
\hline \multicolumn{1}{c}{ Game } & \multicolumn{1}{c}{ Decision Rules } & \multicolumn{1}{c}{ Payoffs } & \multicolumn{1}{c}{ Total Size } \\
\hline $\begin{array}{l}\text { Test for Contract Rule } \\
\text { (Ultimatum Game) }\end{array}$ & $\begin{array}{l}\text { Player 1 makes and } \\
\text { offer which Player 2 can } \\
\text { decide to accept or } \\
\text { reject }\end{array}$ & $\begin{array}{l}\text { If Player 2 accepts the } \\
\text { offer, both players } \\
\text { keep the money. }\end{array}$ & 38 Non-Muslim (22 \\
& If Player 2 rejects, & -19 Offerers (11 primed) \\
& then both players lose & primed) \\
& all their money. & 32 Muslim (16 primed) \\
& & -16 Offerers (7 primed) \\
& & -16 Responders (9 \\
& & primed) \\
\hline
\end{tabular}

IJIEF: InternationalJournal of Islamic Economics and Finance, 1(2), 123-144 |132 


\section{Results and Analysis}

\section{Results}

In previous experiments, the average accepted offers were about $50 \%$ of the original sumgiven to the second player. It is not surprising that low offers (below 25\%) are more likely to be rejected while higher offers were more likely to be accepted (from Kahneman,et al., 1986; Camerer, 2003; etc). By the axiomatic assumption of classical economics on rationality and selfinterest, the players would be expected to be motivated by some monetary incentive, and hence the subgame-perfect equilibrium prediction would expect player $A$ to offer the smallest monetary unit possible to player $B$, and player $B$ accepting that offer regardless how small. From that economic perspective, any amount offered no matter how small is better than nothing, so by that rationality player B's response should be to accept even small offers. However, previous experiments have shown that often times this payoff outcome does not happen, which tend to point to the flaw in economic assumptions of procedural rationality. In its place, actual human behavior is consistent with taking additional, immaterial, non-pecuniary considerationsinto account, such as self-worth, honor, values such as fairness, even when they are no opportunities for bargaining and the game is not repeated between the same players.

In our experiment, the players were grouped as offerers and responders. There were:

$$
\begin{aligned}
& \text { Islamicofferers }-7(\mathrm{SG})+9(\mathrm{MY})=16 \text { (7 are primed) } \\
& \text { Non-Islamicofferers }-8(\mathrm{SG})+11(\mathrm{MY})=19(12 \text { are primed }) \\
& \text { Islamic responders }-5(\mathrm{SG})+11(\mathrm{MY})=16(9 \text { are primed }) \\
& \text { Non-Islamic responders }-10(\mathrm{SG})+9(\mathrm{MY})=19(10 \text { are primed })
\end{aligned}
$$

which makes 35 offerers and 35 responders of 70 in total of which 38 are primed.

In both countries where our experiments ran, the results of replicated other documented Ultimatum Games with more than $50 \%$ of the offers gravitating to the $50 \%$ value of $\$ \$ 20$ at $\$ \$ 10$ regardless of priming effects. However, lower offers of $\mathbf{\$} \$ 4$ and $\$ \$ 6$ were not rejected in our sample as expected (typically offers of $<25 \%$ are rejected although our lower offers were between 20-30\%).

Conventional economic theory predicts that any dollar/ringgit amount will make the second player economically better off and so he/she should accept it, and our results of no rejection to lower than $50 \%$ offers seem to followthat theory. For our analysis, we focus on the $50 \%$ offers (i.e. $\$ \$ 10$ and 
Mohamed| Investigating Fairness in Economic Transactions: Evidence in Belief Systems

RM10) because it is more or less representative of the Ultimatum Game outcomes (about $50 \%$ offers seem to be the norm) and it is considered as the "fair" outcome.

When the data of the Islamic and non-Islamic players were combined, the results seem to suggest that the primed and unprimed segments were almost similarly inclined to make a fair offer (i.e. about $80 \%$ of all offerers made the $50 \%$ offer). However, the priming effects had a more positive correlation for Islamic group (86\% primed versus 67\% unprimed) compared to non-Islamic group who indicated negative priming effects; $75 \%$ of the primed subjects made fair offers as compared to $100 \%$ of those who were not primed. For the Islamic group, the primes did in fact nudged Islamic subjects to honor fairness and make more fair offers (86\% primed Islamic versus $79 \%$ of all primed subjects). But the negative results for the nonIslamic group seem puzzling; no correlations with the subject profiles nor country characteristics could explain this. It seems to indicate that when religiously primed, non-Islamic players seem to act less fairly, but made $100 \%$ fair offers when not primed. 
Table 2: Breakdown of Offerers and 50\% Offers by Numbers and Ratios.

\begin{tabular}{|c|c|c|c|}
\hline Total Number of Offerers & Singapore & Malaysia & SG \& MY \\
\hline Muslim & 7 & 9 & 16 \\
\hline Primed & 3 & 4 & 7 \\
\hline Unprimed & 4 & 5 & 9 \\
\hline Non-Muslim & 8 & 11 & 19 \\
\hline Primed & 6 & 6 & 12 \\
\hline Unprimed & 2 & 5 & 7 \\
\hline Combined (M \& nM) & 15 & 20 & 35 \\
\hline Primed & 9 & 10 & 19 \\
\hline Unprimed & 6 & 10 & 16 \\
\hline \multicolumn{4}{|c|}{ Subjects Who Made $50 \%$ Offers (i.e. $\mathbf{S \$ 1 0}$ or RM10) } \\
\hline Muslim & 6 & 6 & 12 \\
\hline Primed & 3 & 3 & 6 \\
\hline Unprimed & 3 & 3 & 6 \\
\hline Non-Muslim & 6 & 10 & 16 \\
\hline Primed & 4 & 5 & 9 \\
\hline Unprimed & 2 & 5 & 7 \\
\hline Combined (M \& nM) & 12 & 16 & 28 \\
\hline Primed & 7 & 8 & 15 \\
\hline Unprimed & 5 & 8 & 13 \\
\hline \multicolumn{4}{|c|}{ Ratio of Subjects Who Made $50 \%$ Offers (i.e. S\$10 or RM10) } \\
\hline Muslim & $86 \%$ & $67 \%$ & $75 \%$ \\
\hline Primed & $100 \%$ & $75 \%$ & $86 \%$ \\
\hline Unprimed & $75 \%$ & $60 \%$ & $67 \%$ \\
\hline Non-Muslim & $75 \%$ & $91 \%$ & $84 \%$ \\
\hline Primed & $67 \%$ & $83 \%$ & $75 \%$ \\
\hline Unprimed & $100 \%$ & $100 \%$ & $100 \%$ \\
\hline Combined (M \& nM) & $80 \%$ & $80 \%$ & $80 \%$ \\
\hline Primed & $78 \%$ & $80 \%$ & $79 \%$ \\
\hline Unprimed & $83 \%$ & $80 \%$ & $81 \%$ \\
\hline
\end{tabular}

Interestingly, the one offer that was rejected was a fair one at RM10 but the responder (a primed Muslim) rejected it due to personal reasons. When prodded why she rejected it after the session, she said that she will not accept any money without having to work for it- part of her family value system. This rejection clearly signifies that there are other ethical sensitivities involved. This concept of other ethical/moral considerations is also validated by the two maximum offers (S\$20 and RM20) and two 75\% offers (RM15) by offerers who justified their decisions by "wanting the best for others" and "wanting to be generous" respectively. 


\section{Analysis}

Benevolence in experimental investigations is usually deducedin gametheoretic models as a preference for fairness or equitable outcome. Several "inherent social justice" theories try to summarize this observed big heartedness by assuming that it reflects an inclination for equitable outcomes or social wellbeing. For instance, people may distribute portions to others because they achieve satisfaction through others' payoffs (Andreoni and Miller, 2000), are opposed to unequal payoff differences (Fehr and Schmidt, 1999; Bolton and Ockenfels, 2000), or want to maximize the total social payoffs or enforce the lowest payoff to any one party (Charness and Rabin, 2002; Engelmann and Strobel, 2004) as punishment. The shared feature of these analyses or interpretations is that they assume that players' preferences can be based on the final distributions of wealth.

However, there are several reasons as to why people seem to gravitate to fairness and equity. Their motives vary from uncertainty reduction and selfenhancement (individual self-image), the motives of reputation and status (collective self-image), and the motives of belongingness and respect (Sedikides,et al., 2008). Other experiments seem to indicate that one possibility is that people at times feel obliged to give in to situational considerations, without really giving attention toa fair and just outcome. By relaxing transparency in decisions, Dana, et al. (2007) found that when given "moral wiggle room" players behaved self-interestedly, and their results showed significantly less fair behaviors.

Table 3: Overall Performance for both Cities (Islamic and Priming Effects).

\begin{tabular}{|c|c|}
\hline SUMMARY & \\
\hline & Rule of Contract \\
\hline \multicolumn{2}{|l|}{ Muslim } \\
\hline Priming Effects & $P>U n P$ \\
\hline \multicolumn{2}{|l|}{ Non-Muslim } \\
\hline Priming Effects & $\mathrm{P}<$ UnP \\
\hline \multicolumn{2}{|l|}{ Combined ( $M$ \& nM) } \\
\hline Priming Effects & $\mathrm{P}<$ UnP \\
\hline Muslim vs non-Muslim & $M<$ nonM \\
\hline
\end{tabular}

where $\mathrm{P}=$ primed; UnP = unprimed subjects and $\mathrm{M}=$ Muslim and nonM = non-Muslim participants and $>$ means performs better and $<$ means conversely according to the primary criteria of the experimental game 
The outcomes of our experiments seem to suggest that the influence of the Islamic identity seem to positively trigger pro-social behaviors resulting in more fairness in the Muslim group than when unprimed. The non-Muslim players appear to have started with fairness as default (without any religious priming) but became less fair after being primed. One possible explanation could be that the priming resulted in them being driven by selfenhancement regardless of how they were being perceived. This view is substantiated by previous experiments like Benabou and Tirole (2006) who reformulated Weber's findings (1952) of Protestant ethics of working hard where religious people derive positive motivation for efforts geared towards the promise of rewards in the afterlife for people who work hard and do good on earth. These people chose higher effort levels and demanded less redistribution in equilibrium. This type of egalitarian justice is different from the distributive justice that philosophers like Rawls proposes in his Theory of Justice. This also seems to support other empirical findings on experiments involving non-Muslim societies as in Palani (2008) and in Rees (2009), where it was establishedthat significant income differences are more apparent in countries with greaterreligiosity. In contrast, Steven Fish finds that all around the world, "socioeconomic inequality is lower in societies with proportionally larger Muslim populations" (2011). This could be attributed to the inherent distributive mechanism of zakat that is mandatory in Muslim societies with respect to income and wealth distribution. Hence, the expectation of fair outcomes seems to stem from the religious duty of zakat - the fourth pillar of Islam - which is confirmed by our results from Islamic religious priming. The redistributive power of the zakat system ensures the rights for equality across socio-economic groups, and it appears to be reducing disparity for a more equitable society. In doing so, the Islamic concept of fairness may include the desire for others to have a better life.

Upon closer scrutiny of our results, we observe that players who are older (50s), female (2 out of 7) and the lower-middle income group (2 out of 7) were the ones who gave low offers, where the younger (20s, 30s, 40s) males ( 8 out of 8 ) and more affluent gave fair offers ( $\$ 10$ and above). But this is only apparent in the Singapore group. There was no significant difference of such segments, i.e. age, gender and income, for the Malaysian group. Here, it may appear that in fairness and just distribution, all Malaysians take a more pro-social view and Singaporeans seem to be more individualistic. As the results suggest, Malaysians felt that it is within their own actions to promote fairness and justice, whilst possibly, that some Singaporeans view that responsibility does not fall on them (from their individualistic choices), perhaps rather that it belongs to the State to enforce and regulate. 


\section{Conclusion and Recommendation}

\section{Conclusion}

Various religious traditions advance diverse teachings and apply different frames, and this is indeed true in how they address social and economic norms. Investigating how religion influences fairness and just distribution beliefs includes reviewing the basic teachings of the major traditions and how each addresses distribution, equality and fairness. There are many factors and nuances involved and it is naturally more complex than experiment outcomes suggest.

In broad terms, religiosity does not oppose the improvement of the living standards of less well-off members of the society. This can be seenfrom the profusion of charitable organizations whose major champions are religious people. As such, it becomes crucial to understand whether this negative correlation in the non-Muslim group is due to the differences in normative understanding of their religious beliefs or in their household/social conditioning that influences the expressions of their religion to produce such outcomes. Nevertheless, our results uncovered a notable difference in fairness concerns by showing a positive correlation between fairness perceptions of Muslims and their religious beliefs. Where fairness and just outcomes are needed, Muslims should be primed to be more religious.

Finally, if religious beliefs influence the direction of each group's perceptions and are likely to have opposing views on the issues of fairness and just distribution, then it is imperative that institutions and governments be aware of such disparities for effective policy formulation or any initiatives to be undertaken. It may be useful in determining where subsidies, taxation and welfare-spending can be allocated for which groups, or at least when policies are being formulated, how they would be perceived by certain groups in different jurisdictions.

\section{Recommendation}

Due to the consequences of a breach of contract, it is advisable then that a section on some important issues when going into an agreement and drafting a contract to ensure fairness and equity. The following are some suggestions and some legal points to note in carrying out business and trade in the present day.

i. While drafting a contract or agreement or while vetting a draft, the parties need to go through carefully about various obligations, 
rights, consequence of default, remedies available etc. Results to be achieved and time limits thereof have to be spelt out with sufficient clarity. Where the parties intend to enforce specific performance or to restore status quo ante, it is better to provide a specific clause. Sufficient clarity is required to be added as to the mechanism for dispute resolution and jurisdiction of the courts.

ii. In contractual fairness, it is the responsibility of contracting parties to mitigate damages. The party who is liable for loss from breach of contract should intuitively take reasonable steps to abate the extent of loss or damage. Also, in fairness outcomes, the plaintiff should not act unreasonably and hold defendant liable to loss completely without reasonable opportunities of remedy.

iii. Extenuation is especially important in sale and purchase contracts. For fair outcomes, the seller should resell the goods at market price and recover the difference (if any), if the buyer refuses to take delivery of the goods. Likewise, if seller breaches and cannot complete delivery, the buyer should be compensated with similar goods from any alternative sources, where available.

iv. It is desirable in fair dealings that all extensions of time granted to the deliverer should be allowed, in writing, and should be such that it is not partial to the rights of the counterparty to recover liquidated damages for the delay and/or to cancel the contract and make alternate arrangements. Such extensions granted should be without any additional financial implications to the other party. Further contract variations henceforth should be mutually agreed upon. In addition, the party giving more time for extension has to indicate intention to claim compensation, or it would be deemed to have waived such right.

v. In cases of compensation for the aggrieved party for the loss suffered, the aggrieved party has no right to make a profit out of this. Hence, despite parties having agreed to a fixed amount payable as damages, the aggrieved party will only get what is due to him/her, nothing exceeding the actual loss suffered.

vi. It should be clarified that the objective of having liquidated damages clause in contracts is only to safe guard the diligence and workmanlike execution of the contractual agreement, and endeavor to finish the whole work as given in the contract within the specified time. It must be remembered that the specification with regard to liquidated damages is not designed to provide unjust enrichment to the beneficiary. It should be viewed that recourse to imposition of liquidated damages should be reserved for extreme cases and amiable relationship continues between the parties for future business. Unwanted disputes will cause many unnecessary legal and 
Mohamed| Investigating Fairness in Economic Transactions: Evidence in Belief Systems

financial complications. There may be a legal ruling from the courts restraining the party from continuing the work, pending the court's decision on the case.

vii. Complexity and ambiguity of modern transactions in the global market has made the classical legal analysis of rules of contract law increasingly inadequate. Contracting parties can no longer optimally bargain future arrangements. Contracts built on strong relationships can safeguard complicated arrangements such as agency and employment contracts. There is no contract that is completely contingent on all terms and conditions.

viii. Ensuring that all contractual legal issues are managed adequately is essential to sustainable business operations by securing profitability to the organization. Proper contract management warrants that both contracting parties meet their respective obligations as effectively as possible, in order to achieve the mutual business objectives under the contract they had agreed on. 


\section{References}

Andreoni, J. and Miller, J. (2002). Giving According to GARP: An Experimental Test of the Consistency of Preferences for Altruism. Econometrica 70, 737-753.

Atiyah, P.S. (1985). Contract and Fair Exchange, University of Toronto Law Journal, 1.

Blake, P.R., and McAuliffe, K. (2011). "I Had So Much It Didn't Seem Fair": Eight-Year-Olds Reject Two Forms of Inequity. Cognition, 120, 215224.

Blau, P. (1964). Justice in Social Exchange. Sociological Inquiry, 34, 193-206.

Bloom, P. (2013). Just Babies: The Origins of Good and Evil. Crown Publishing Group.

Boehm, C. (2008). Purposive Social Selection and the Evolution of Human Altruism. Cross-Cultural Research, 42, 319-352.

Bolton, G.E., Ockenfels, A. (2005). A Stress Test of Fairness Measures in Models of Social Utility. Econ Theory 25(4), 957-982.

Charness, G., Rabin, M. (2002). Understanding Social Preferences with Simple Tests. Quarterly Journal of Economics 117, 817-869.

Dana, J., Weber, R.A. and Kuang, J.X. (2007). Exploiting Moral Wiggle Room: Experiments Demonstrating an Illusory Preference for Fairness. Economic Theory, 33, 67-80.

Danuri, M., Suhaimi, M., Hussain, S.M., Mustaffa, N.E., Jaafar M.S. (2010). Growth of Dispute Avoidance Procedure in the Construction Industry: A Revisit and New Perspectives. Const. L. J., 26(5), 347-361.

De Cremer, D., and Sedikides, C. (2008). Reputational Implications of Fairness for Personal and Relational Self-esteem. Basic and Applied Social Psychology, 30, 66-75.

DiMatteo, L. A. (1995). The Norms of Contract: The Fairness Inquiry and the Law of Satisfaction-A Nonunified Theory, Hofstra Law Review: Vol. 24: Issue 2, Article 8.

Engelmann, D. and Strobel, M. (2004). Inequality Aversion, Efficiency, and Maximin Preferences in Simple Distribution Experiments. Am Econ Rev 94, 857-869.

Fehr, E. and Schmidt, K. M. (1999). A Theory of Fairness, Competition and Cooperation. Q J Econ 114, 817-868.

Fehr, E., Goette, L. and Zehnder, C. (2009). A Behavioral Account of the Labor Market: The Role of Fairness Concerns. Annual Review of Economics, 1, 355-384.

Fish, M. S. (2011). Are Muslims Distinctive? A Look at The Evidence. Oxford University Press.

Frankfurt, H. (2015). On Inequality. Princeton, NJ: Princeton University Press.

Franzen, A. and Pointner, S. (2012). Anonymity in the Dictator Game Revisited. Journal of Economic Behavior \& Organization, 81, 7481.

Habachy, S. (1962). Property, Right, and Contract in Muslim law. Columbia Law Review 62(3), 450-473. 
Mohamed| Investigating Fairness in Economic Transactions: Evidence in Belief Systems

Henrich, J., Boyd, R., Bowles, S., Camerer, C., Fehr, E., and Gintis, H. (2004). Foundations of Human Sociality: Economic Experiments and Ethnographic Evidence from Fifteen Small-Scale Societies. Oxford, U.K.: Oxford University Press.

Kagel, J., Kim, C. and Moser, D. (1996). Fairness in Ultimatum Games with Asymmetric Information and Asymmetric Payoffs. Games and Economic Behavior, 13, 100-110.

Kahneman, D., Knetsch, J. and Thaler, R. (1986) Fairness and the Assumptions of Economics. Journal of Business 59, 285-300.

Knack, S. and Keefer P. (1997). Does Social Capital Have an Economic Payoff? A Cross-country Investigation, in: Quarterly Journal of Economics, No. 112, 1997, pp.1251-1288.

Li, K.J. and Jain, S. (2015). Behavior-Based Pricing: An Analysis of the Impact of Peer-Induced Fairness. Management Science, 62 (9), 2705-2721.

Palani, P. (2008). The Effect of Religiosity on Income Inequality, Journal of Politics and International Affairs, 61-70.

Rees, T.J. (2009). Is Personal Insecurity a Cause of Cross-National Differences in the Intensity of Religious Belief? Journal of Religion and Society, 11, 1-17.

Rothstein, B. and Uslaner, E. (2005). All for All: Equality and Social Trust, in: LSE Health and Social Care Discussion Paper, Number 15, London School of Economics and Political Science.

Sedikides, C., Hart, C.M. and De Cremer, D. (2008). The Self in Procedural Fairness Social and Personality, Psychology Compass 2/6, 21072124.

Shariff, A. and Norenzayan, A. (2007). God Is Watching You: Priming God Concepts Increases Prosocial Behavior in an Anonymous Economic Game. Psychological Science 18, 803-809.

Shaw, A., DeScioli, P., and Olson, K.R. (2012). Fairness versus Favoritism in Children. Evolution and Human Behavior, 33, 736-745.

Shaw, A., and Olson, K. R. (2012). Children Discard A Resource to Avoid Inequity. Journal of Experimental Psychology: General, 141, 382-395.

Simon, H. (1976). From Substantive to Procedural Rationality. In Method and Appraisal in Economics, edited by Spiro J. Latsis, 129-48. Cambridge, U.K.: Cambridge University Press.

Tyler, T. R. (1994). Governing amid Diversity: The Effect of Fair Decisionmaking Procedures on the Legitimacy of Government. Law and Society Review, 28, 809-831

Weber, M. (1952). The Protestant Ethic and the Spirit of Capitalism. New York, NY: Scribner.

Wheeler, S.C. and Petty, R.E. (2001). The Effects of Stereotype Activation on Behavior: A Review of Possible Mechanisms. Psychological Bulletin 127(6), 797-826. 


\section{Appendix}

\section{Appendix 1a: Sample Size and Ratios of Background Spread}

\begin{tabular}{|c|c|c|c|c|}
\hline Sample Size & Singapore & Malaysia & Total & Ratio \\
\hline Sample Sub-total & 30 & 40 & 70 & $100 \%$ \\
\hline Muslim & 12 & 20 & 32 & $46 \%$ \\
\hline Non-Muslim & 18 & 20 & 38 & $54 \%$ \\
\hline Atheist & 1 & 0 & 1 & \\
\hline Buddhist & 6 & 10 & 16 & \\
\hline Catholic & 3 & 1 & 4 & \\
\hline Christian (non-Catholic) & 1 & 3 & 4 & \\
\hline Free-thinker & 5 & 3 & 8 & \\
\hline Hindu & 1 & 3 & 4 & \\
\hline Taoist & 1 & 0 & 1 & \\
\hline Age & 30 & 40 & 70 & $100 \%$ \\
\hline $20 \mathrm{~s}$ & 10 & 18 & 28 & $40 \%$ \\
\hline $30 \mathrm{~s}$ & 10 & 16 & 26 & $37 \%$ \\
\hline $40 \mathrm{~s}$ & 9 & 6 & 15 & $21 \%$ \\
\hline $50 \mathrm{~s}$ & 1 & 0 & 1 & $1 \%$ \\
\hline Gender & 30 & 40 & 70 & $100 \%$ \\
\hline Male & 17 & 20 & 37 & $53 \%$ \\
\hline Female & 13 & 20 & 33 & $47 \%$ \\
\hline Education & 30 & 40 & 70 & $100 \%$ \\
\hline Tertiary & 19 & 38 & 57 & $81 \%$ \\
\hline Non-tertiary & 11 & 2 & 13 & $19 \%$ \\
\hline Income & 30 & 40 & 70 & $100 \%$ \\
\hline$<$ S\$/RM24k per annum & 6 & 14 & 20 & $29 \%$ \\
\hline $\mathrm{S} \$ / \mathrm{RM} 24 \mathrm{k}$ to $36 \mathrm{k}$ per ann & 14 & 13 & 27 & $39 \%$ \\
\hline S\$/RM36k to $48 \mathrm{k}$ per anni & 6 & 10 & 16 & $23 \%$ \\
\hline > S\$/RM72k per annum & 4 & 3 & 7 & $10 \%$ \\
\hline
\end{tabular}


Mohamed| Investigating Fairness in Economic Transactions: Evidence in Belief Systems

Appendix 1b: Size/Ratios of Muslim vs non-Muslim and Primed vs Unprimed Groupings

\begin{tabular}{|c|c|c|c|}
\hline Sample Size & Singapore & Malaysia & Total \\
\hline Sample Sub-total & 30 & 40 & 70 \\
\hline Muslim & 12 & 20 & 32 \\
\hline Non-Muslim & 18 & 20 & 38 \\
\hline Primed & 18 & 20 & 38 \\
\hline Muslim & 7 & 9 & 16 \\
\hline Non-Muslim & 11 & 11 & 22 \\
\hline Unprimed & 12 & 20 & 32 \\
\hline Muslim & 5 & 11 & 16 \\
\hline Non-Muslim & 7 & 9 & 16 \\
\hline Ratios (\%) & Singapore & Malaysia & Total \\
\hline Sample Sub-total & $100 \%$ & $100 \%$ & $100 \%$ \\
\hline Muslim & $40 \%$ & $50 \%$ & $46 \%$ \\
\hline Non-Muslim & $60 \%$ & $50 \%$ & $54 \%$ \\
\hline Primed & $60 \%$ & $50 \%$ & $54 \%$ \\
\hline Muslim & $23 \%$ & $23 \%$ & $23 \%$ \\
\hline Non-Muslim & $37 \%$ & $28 \%$ & $31 \%$ \\
\hline Unprimed & $40 \%$ & $50 \%$ & $46 \%$ \\
\hline Muslim & $17 \%$ & $28 \%$ & $23 \%$ \\
\hline Non-Muslim & $23 \%$ & $23 \%$ & $23 \%$ \\
\hline
\end{tabular}

